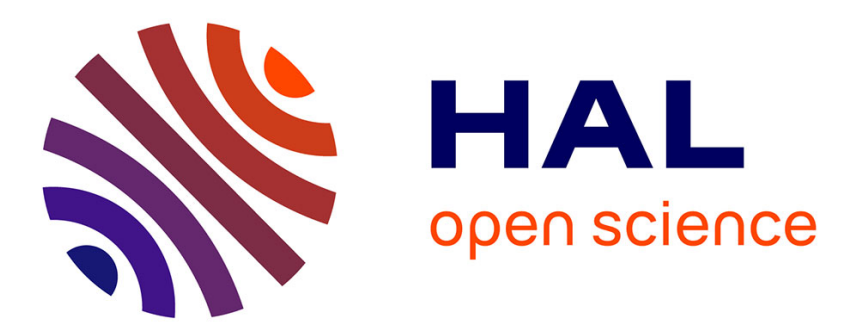

\title{
Zoledronic acid determines S-phase arrest but fails to induce apoptosis in cholangiocarcinoma cells
}

\author{
Antonello A. Romani, Silvia Desenzani, Marina M. Morganti, Silvia La \\ Monica, Angelo F. Borghetti, Paolo Soliani
}

\section{To cite this version:}

Antonello A. Romani, Silvia Desenzani, Marina M. Morganti, Silvia La Monica, Angelo F. Borghetti, et al.. Zoledronic acid determines S-phase arrest but fails to induce apoptosis in cholangiocarcinoma cells. Biochemical Pharmacology, 2009, 78 (2), pp.133. 10.1016/j.bcp.2009.04.004 . hal-00493514

\section{HAL Id: hal-00493514 \\ https://hal.science/hal-00493514}

Submitted on 19 Jun 2010

HAL is a multi-disciplinary open access archive for the deposit and dissemination of scientific research documents, whether they are published or not. The documents may come from teaching and research institutions in France or abroad, or from public or private research centers.
L'archive ouverte pluridisciplinaire HAL, est destinée au dépôt et à la diffusion de documents scientifiques de niveau recherche, publiés ou non, émanant des établissements d'enseignement et de recherche français ou étrangers, des laboratoires publics ou privés. 


\section{Accepted Manuscript}

Title: Zoledronic acid determines S-phase arrest but fails to induce apoptosis in cholangiocarcinoma cells

Authors: Antonello A. Romani, Silvia Desenzani, Marina M. Morganti, Silvia La Monica, Angelo F. Borghetti, Paolo

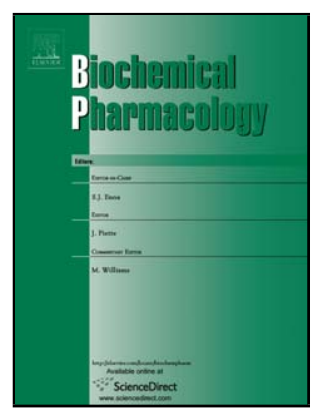

Soliani

PII: S0006-2952(09)00259-7

DOI: doi:10.1016/j.bcp.2009.04.004

Reference: BCP 10138

To appear in: $\quad B C P$

Received date: $\quad 8-12-2008$

Revised date: $\quad$ 13-3-2009

Accepted date: $\quad$ 2-4-2009

Please cite this article as: Romani AA, Desenzani S, Morganti MM, La Monica S, Borghetti AF, Soliani P, Zoledronic acid determines S-phase arrest but fails to induce apoptosis in cholangiocarcinoma cells, Biochemical Pharmacology (2008), doi:10.1016/j.bcp.2009.04.004

This is a PDF file of an unedited manuscript that has been accepted for publication. As a service to our customers we are providing this early version of the manuscript. The manuscript will undergo copyediting, typesetting, and review of the resulting proof before it is published in its final form. Please note that during the production process errors may be discovered which could affect the content, and all legal disclaimers that apply to the journal pertain. 


\section{Zoledronic acid determines S-phase arrest but fails to induce apoptosis in cholangiocarcinoma cells}

${ }^{1 *}$ Antonello A. Romani, ${ }^{1 *}$ Silvia Desenzani, ${ }^{1}$ Marina M. Morganti, ${ }^{1}$ Silvia La Monica, ${ }^{1 \S}$ Angelo F. Borghetti and ${ }^{2}$ Paolo Soliani

${ }^{1}$ Dipartimento di Medicina Sperimentale - Sezione di Patologia Molecolare ed Immunologia,

${ }^{2}$ Dipartimento di Scienze Chirurgiche - Sezione di Clinica Chirurgica Generale e dei Trapianti d'Organo, Università degli Studi di Parma

* These authors equally contributed to the article

${ }^{\S}$ Corresponding Author:

Angelo F. Borghetti, MD, PhD

Dipartimento di Medicina Sperimentale

Sezione di Patologia Molecolare ed Immunologia

via Volturno 39, 43100 Parma, Italy

email: angelo.borghetti@unipr.it

Keywords: Cholangiocarcinoma, Zoledronic acid, Cyclins, Cell cycle regulators, Bcl-xL, GGOH 


\section{ABSTRACT}

Cholangiocarcinoma is the second most common primary hepatic neoplasia and the only curative therapy is surgical resection or liver transplantation. Biphosphonates (BPs) are an emerging class of drugs widely used to treat bone diseases and also appear to possess direct antitumor activity. In two human cholangiocarcinoma cell lines (TFK-1 and EGI-1) we investigated, for the first time, the activity of zoledronic acid by determining proliferation, cell-cycle analysis and apoptosis.

The results obtained indicate that zoledronic acid induces cell-narrowing and growth inhibition, both reversed by $25 \mu \mathrm{M}$ GGOH, and significantly affects the colony-forming ability of these cells. The inhibition by zoledronic acid of Rap1A prenylation was reversed in cell co-treated with GGOH. At 10-50 $\mu \mathrm{M}$ zoledronic acid exerted an S-phase cell cycle arrest which was confirmed by changes in the level of cyclins and of regulators $\mathrm{p} 27^{\mathrm{KIP} 1}$ and $\mathrm{pRb}$. Interestingly, the expression level of cyclin A (putative S-phase marker) shows a dose-dependent increment in contrast to the decrement of cyclin D1 (putative G1-phase marker). However, neither hypodiploid cells nor cleaved PARP or caspase-3 were detected. The lack of TP53 or loss of its function, the large constitutive expressions of antiapoptotic proteins Bcl-xL and HSP27 together with the low level of the proapoptotic Bax are the likely factors which protect cells from apoptosis.

In conclusion, our study indicates that zoledronic acid induces S-phase arrest and cell-narrowing, both reversed by GGOH and, by changing the delicate balance between pro-apoptotic and antiapoptotic proteins, allows survival of cholangiocarcinoma cells.

Running title: S-phase arrest by zoledronate in cholangiocarcinoma 


\section{Introduction}

Cholangiocarcinoma are malignant tumors that derive from bile duct epithelium and are classified anatomically into intra- and extra-hepatic cholangiocarcinoma. The incidence and the mortality rates of cholangiocarcinoma are increasing worldwide[1]. At present, complete resection is the only way to cure this disease, but at the time of diagnoses more than $60 \%$ of patients have occult metastases or an advanced local disease which preclude any curative resection. Conventional anticancer treatments, such as chemotherapy or radiotherapy have minimal impact on patients survival with unresectable tumor[2-5]. Up to now, the factors responsible for this relative unresponsiveness have not been clearly understood. In general, the efficacy of conventional anticancer therapies is strongly dependent on their ability to initiate programmed cell death (apoptosis) in cancer cells[6-8]. Therefore, cancer cells that have evolved ways to circumvent apoptosis become resistant, providing an obstacle to effective treatments $[9$, $10]$.

Previous researchers have shown that zoledronic acid (ZOL), third generation of biphosphonates (BPs), exerts powerful antitumoral activity[11] in several human neoplasms[11] such as human myeloma[12], breast[13] and prostate[14, 15] cancers. BPs are currently the most important class of inhibitors of osteoclast-mediated bone resorption and are used extensively for the treatment of skeletal diseases, such as Paget's disease, postmenopausal osteoporosis, and tumor-induced osteolysis[16, 17]. The antiproliferative effect of pamidronate in human and rat osteosarcoma cells has recently been demonstrated in vitro $[18,19]$. BPs can be divided into two distinct pharmacological classes based on their molecular mechanisms of action[20]. Non-nitrogencontaining BPs, such as clodronate and etidronate, are metabolized intracellularly as cytotoxic analogues of ATP and thus inhibit osteoclast activity[21]. In contrast, the newer nitrogen- 
containing BPs such as alendronate, residronate, pamidronate, and ZOL inhibit cell proliferation and induce apoptosis in osteoclasts[22] by inhibiting farnesyl-PP-synthase of the mevalonate synthesis, a biosynthetic pathway responsible for the production of cholesterol and isoprenoid lipids, particularly farnesyl- and geranylpyrophosphates. These are required for the posttranslational modification (prenylation) of small GTP proteins (such as Rho, Ras, Rac) that play crucial roles in signaling pathways controlling cell growth. The anti-proliferative effect of ZOL was described in several tumor cell lines and it was likely due to cell cycle distribution change by accumulating and arresting cells in the S-phase[23-27]. This arrest was coupled to changing levels of cyclins and cell cycle regulators, and the S-phase arrest was associated with typical (caspase-dependent)[25, 27, 28] or atypical (caspase-independent) apoptotic pathway. To date, however, the detailed molecular mechanism of cell cycle arrest involved remains not fully understood.

Since most of patients with cholangiocarcinoma present at diagnoses with unresectable disease or the occurrence, in this cancer, of high-rate of post-resection relapse, the current adjuvant or palliative option is of limited benefit. It is mandatory, therefore, to evaluate new potential anticancer drugs. ZOL, due to its mechanism of action so far highlighted, could represent a reliable chemotherapeutic agent able to sensitize cells to cytotoxic agents and/or radiations.

Here we investigated, for the first time on two cholangiocarcinoma cell lines, the role of ZOL on cell morphology, proliferation, cycle phases, and apoptosis to regard its potential use in cholangiocarcinoma therapy. 


\section{Methods and Materials}

\subsection{Reagents}

Zoledronic acid (ZOL, ZOMETA®, Novartis Europharm, UK ) and gemcitabine (GEM, GEMZAR®, Eli Lilly, Italy) were kindly provided by Drs. Vittorio Rizzoli and Maria Cristina Baroni, Dipartimento di Medicina Interna e Scienze Biomediche, Università degli Studi di Parma. ZOL was dissolved in phosphate buffer saline (PBS) as a $5 \mathrm{mM}$ stock solution while GEM as $100 \mathrm{mM}$ stock solution and both stored at $-20^{\circ} \mathrm{C}$. RPMI 1640 medium, staurosporine, geranylgeraniol (GGOH), pamidronate, clodronate, and phosphorylated histone H3 (pHH3, 8656R), were purchased from Sigma-Aldrich (St. Louis, MO, USA), and fetal bovine serum (FBS) from Gibco-BRL (Grand Island, NY, USA). Antibodies against Bcl-xL (H-5), Bax (P-19), TP53 (DO-1), Rap1A (SC-1482, unprenylated form) were obtained from Santa Cruz Biotechnology (Santa Cruz, Temecula, CA, USA). Monoclonal antibody against HSP27 (G3.1) was from StressGene (Victoria, BC Canada); caspase-3, PARP, cyclin A, cyclin B1, cyclin D1, pRb1, Rb, and p27 antibodies were from Cell Signaling Technologies (Beverly, MA, USA); monoclonal anti-actin (AC-40) antibody was from Sigma Aldrich. HRP-conjugated secondary antibodies (Pierce, Rockford, IL, USA) and the enhanced chemiluminescence system (ECL) were from Millipore (Millipore Co, Billerica, MA, USA). Reagents for electrophoresis and blotting analysis were obtained from BIO-RAD Laboratories (Richmond, CA, USA). 


\subsection{Cell culture}

The cholangiocarcinoma cell lines EGI-1 and TFK-1 were obtained from the DSMZ (Deutsche Sammlung von Mikroorganismen und Zellkulturen, Braunschweig, GERMANY) and maintained in RPMI-1640 medium, containing antibiotics (100 U/ml penicillin, $100 \mu \mathrm{g} / \mathrm{ml}$ streptomycin) and supplemented with $10 \%$ FCS and with $2 \mathrm{mmol} / \mathrm{L}$ glutamine. Cultures were kept in an incubator at $37^{\circ} \mathrm{C}$ in a water-saturated $5 \% \mathrm{CO}_{2}$ atmosphere in air. Routine sub-cultivations were carried out every week. Cell morphology was assessed on May-Grünwald stained cells.

\subsection{MTT assay}

Viability of EGI-1 and TFK-1 cells was evaluated by [3-(4,5-dimethylthiazol-2-yl)-2,5diphenyltetrazolium] (MTT) (Sigma-Aldrich) assay. 5000 cells/well were seeded into 96-well plates and left to adhere overnight. The cells were then incubated for 3 days in the absence or in the presence of 1 to $1000 \mu \mathrm{M}$ ZOL. Then $100 \mu \mathrm{l}$ of $1 \mathrm{mg} / \mathrm{ml}$ MTT were added for $1 \mathrm{~h}$. After removal of the MTT, cells were treated with $100 \mu \mathrm{DMSO}$ and formazan product was solved. The absorbance was determined at $595 \mathrm{~nm}$ in a multiwell plate reader (BIO-RAD, Microplate Reader 555). Drug-induced proliferation changes were calculated as percentage of cell growth inhibition using the formula: (1- extinction of treated sample x 100) / (extinction of control sample). The half-maximal inhibition constant $\left(\mathrm{IC}_{50}\right)$ was determined using the nonlinear regression program CalcuSyn (Biosoft, Cambridge, UK). 


\subsection{Clonogenic assay}

Colony formation was determined by seeding cells into a six-well culture plates at a density of 50 cells $/ \mathrm{cm}^{2}$ well and left to adhere overnight. The cells were then incubated in the absence or in the presence of $2-32 \mu \mathrm{M}$ ZOL. After 10 day-incubation, the wells were washed twice with PBS, and fixed with $1 \%$ formaldehyde. They were then stained with $0.1 \%$ crystal violet. The colony is defined to consist of at least 40-50 cells. For evaluation of cell growth, colonies were examined under a light microscope.

\subsection{Western blotting}

Total proteins were extracted by lysing the cells with a buffer containing 50mM Tris-HCL, pH 7.4, $150 \mathrm{mM} \mathrm{NaCl}, 5 \mathrm{mM} \mathrm{MgCl}_{2}, 0.5 \mathrm{mM}$ EDTA, $0.1 \%$ SDS and protease inhibitor cocktail followed by ultracentrifugation at $13,000 \mathrm{rpm}$ for $10 \mathrm{~min}$. Protein concentration was determined using a protein assay from BIO-RAD according to the manufacturer's protocol, using BSA as standard. Proteins $(50 \mu \mathrm{g})$ were resolved by SDS/PAGE (12\%) and blotted onto PVDF membranes (Millipore). Immunodetection was carried out in 50mM Tris- $\mathrm{HCl}, \mathrm{pH} 7.4,150 \mathrm{mM}$ $\mathrm{NaCl}, 0.1 \%$ Tween $20,5 \%$ non-fat dry milk, followed by HRP conjugated secondary antibodies at 1:20000 dilution. Detection was performed using an ECL kit.

\subsection{Flow cytometric cell cycle and morphological analysis}

Cholangiocarcinoma cells were incubated with 10 and $50 \mu \mathrm{M}$ ZOL for $72 \mathrm{~h}$. For the cell cycle assay EGI-1 and TFK-1 cells were harvested and subjected centrifugation, $5 \times 10^{5}$ cells were 
incubated overnight at $4^{\circ} \mathrm{C}$ in $1 \mathrm{ml}$ of hypotonic fluorochrome solution. DNA content was determined by flow cytometry using a Coulter EPICS XL-MCL cytometer (Coulter Co., Miami, FL, USA) and the cell-cycle-phase distribution was analysed by ModFit 2.0 software (Verity Software House, Topsham, Me. USA). Respective to their phase-specific DNA-content cells were divided into $\mathrm{G} 1, \mathrm{~S}, \mathrm{G} 2 / \mathrm{M}$ phases and, when present, sub-G1 phase counted as apoptotic cells. Cell death was also assessed by morphological criteria on cells stained with Hoechst 33342 (a fluorescent cell-permeant DNA stain) and propidium iodide (PI, a fluorescent permeant stain for membrane damaged cells) using fluorescence microscopy. 


\section{Results}

\subsection{Growth inhibitory effects}

In order to test the effect of ZOL on cholangiocarcinoma cell growth, EGI-1 and TFK-1 cell lines were treated with increasing concentration of ZOL (1 to $1000 \mu \mathrm{M})$ for $72 \mathrm{~h}$, followed by an MTT assay (see Material and Methods section). As revealed in Figure 1, after $72 \mathrm{~h}$ of ZOL treatment cholangiocarcinoma cells significantly reduced their growth in a dose dependent manner. In fact, the tumor cell proliferation was reduced to about $21 \%$ and $50 \%$ for TFK-1 and EGI-1, respectively, at ZOL concentration of $10 \mu \mathrm{M}$. Then inhibition increased to $59 \%$ in TFK-1 and

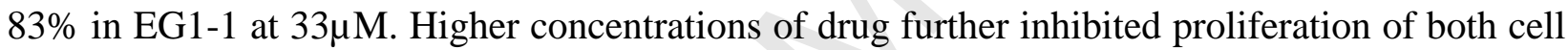
lines. The mean $\mathrm{IC}_{50}$ estimated from three independent experiments gave a concentration of

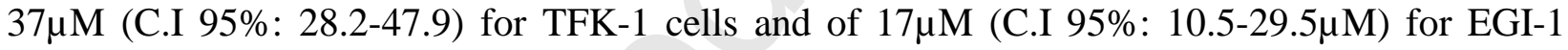
cells.

\subsection{Rescue by GGOH of morphological and proliferation changes induced by ZOL}

Besides the significant inhibition of proliferation induced by ZOL at relatively high concentrations, concomitant alterations of cell morphology occurred. Control cultures (Figure 2A) show typical morphological variations of cholangiocarcinoma cells from cuboidal to-lowcolumnar epithelial cells with rounded to polygonal nuclei. Subsequent to $50 \mu \mathrm{M}$ ZOL treatment long and narrowed cells resembling fibroblasts coupled with a marked reduction of cell number are observed in EGI-1 cells. Similar changes, even if less marked were observed also in TFK-1 cells. To substantiate the mechanism of ZOL activity GGOH, an acyclic isoprenoid substrate of 
protein prenylation, was added during drug treatment. The addition of $25 \mu \mathrm{M} \mathrm{GGOH}$ determines a rescue of zoledronate-induced morphological changes in both cell lines.

The ability of GGOH to attenuate/rescue ZOL cytotoxicity was assessed by plating cells and then treating them with various $\mathrm{ZOL}$ concentrations or in combination with $\mathrm{GGOH}$ as described in the legend to Figure 2B. By using Western blotting analysis in the presence of $50 \mu \mathrm{M}$ of $\mathrm{ZOL}$ the band for the unprenylated form of Rap1A (a small GTP-protein of Ras family) in both cell lines became visible, indicating high level of the unprenylated form. Co-treatment with GGOH significantly attenuated ZOL cytotoxicity, increasing the $\mathrm{IC}_{50}$ by 4.5 -fold and 10 -fold for TFK-1 and EGI-1 cells, respectively. Moreover, GGOH counteracted the ZOL-induced unprenylation of Rap1A in EGI-1 and TFK-1 cells (Figure 2C). This ability of GGOH to alleviate/rescue ZOL toxicity could be ascribed to cell replenishing of substrates for protein prenylation.

\subsection{Loss of clonogenic survival}

Because of the pronounced cytostatic effects of ZOL on cell growth observed on monolayer cultures, we then verified if ZOL could affect the ability of EGI-1 and TFK-1 cells to form colonies in vitro. Clonogenic assay, based on the ability of a single cell to grow into a colony, is the method of choice to determine the effectiveness of cytotoxic agents. After 10 days in culture both EGI-1 and TFK-1 cells, seeded at 50 cells $/ \mathrm{cm}^{2}$, formed a large number of colonies clearly visible at naked eye (Figure 3). However, when cells were grown for ten days in the presence of $8 \mu \mathrm{M}$ ZOL, number and size of TFK-1 and EGI- 1 colonies were markedly reduced. When treated with $16 \mu \mathrm{M}$ ZOL, both cell lines did not form visible colonies. These results clearly indicate that the ZOL treatment determines a long-lasting cell cycle arrest of cholangiocarcinoma cells suppressing their colony-forming ability in a dose-dependent manner. 


\subsection{Cell cycle phase distribution}

We then investigated the effect of $\mathrm{ZOL}$ on the cell cycle phase distribution of cholangiocarcinoma cells following treatment with this drug over a $72 \mathrm{~h}$ period. The analysis (Figure 4) revealed the cell-cycle distribution of untreated control cells showing an average of 70 and $62 \%$ cells in G1, 9 and $11 \%$ in G2/M, and 21 and $28 \%$ in S phase for EGI-1 and TFK-1, respectively. It's interesting to note that when EGI-1 cells were treated with $10 \mu \mathrm{M}$ ZOL for $72 \mathrm{~h}$, the proportion of cells in G1 was reduced to $34 \%$ and $55 \%$ of the cells occurred in S phase, whereas only at $50 \mu \mathrm{M}$ ZOL a marked accumulation of TFK-1 cells in S phase (71\%) occurred. As evident from this figure, the proportion of cells in the $\mathrm{G} 2 / \mathrm{M}$ phase did not change significantly indicating no additional arrest in this phase. In EGI-1 cells a distinct loss of cell in $\mathrm{G} 2 / \mathrm{M}$ phase at the highest drug concentration $(50 \mu \mathrm{M})$ was detectable. Taken together, these results suggest that ZOL treatment for $72 \mathrm{~h}$ induced the entrapment of cholangiocarcinoma cells in the $\mathrm{S}$ phase, resulting, therefore, in an effective reduction of cells capable to complete cell-cycle, and thus leading to a diminished cell proliferation. Interestingly, in both cholangiocarcinoma cell lines, ZOL treatment did not induce any hypodiploid sub-G1 peak, a feature indicative of apoptotic cell death (Figure 4, upper panel). It's worth to note that 48 h co-treatment with GGOH partially rescues the cell-cycle phase distribution seen in ZOL-exposed cholangiocarcinoma cells (data not presented).

\subsection{Expression of putative phase markers and cell cycle regulators}

We then examined the mechanisms of ZOL induced S-phase arrest by focusing on the expression level of phase-specific cyclins and the cell cycle regulators such as tumor suppressor $\mathrm{pRb}$ and 
$\mathrm{p} 27^{\mathrm{KIP} 1}$. Modified expression and/or phosphorylation of these molecules are indicative of which checkpoints may be involved. Checkpoints are important sensors that ensure the proper sequence of cell cycle events allowing cells to repair DNA damage. There are at least three checkpoints at G1/S, S and G2/M phases that can allow DNA repair and promote cell death in unrepaired cells. The first checkpoint at G1/S is often compromised in malignant cells due to deletion or loss of function of TP53, guardian of the genome, and/or mutation of $\mathrm{pRb}$, main regulator of the cell cycle. As shown in Figure 5, while we confirmed the absence of TP53 in TFK-1 cells as known from literature data, its overexpression in EGI-1 cells is likely to be ineffective due to the presence of one deleterious transition mutation $(\mathrm{G}>\mathrm{A}, \mathrm{R} 273 \mathrm{H})$ in the DNA binding domain that prevents its binding to DNA[29]. pRb protein hinders the cell from replicating damaged DNA by preventing its progression along the cell cycle through G1 into S. In the hypophosphorylated state, $\mathrm{pRb}$ protein is active and carries out its role as tumor suppressor by inhibiting cell cycle progression. Phosphorylation inactivates $\mathrm{pRb}$. As shown in Figure 5, in both untreated cell lines the hyperphosphorylation status of $\mathrm{pRb}$ (SER 780) occurred and drug treatment did not affect the

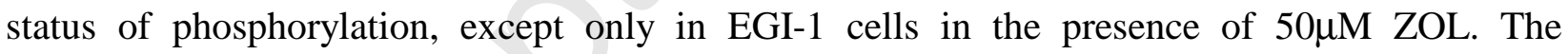
hyperphosphorylation status of $\mathrm{pRb}$ (SER 780) in both treated cell lines associated with a deletion (TFK-1) or deleterious mutation (EGI-1) of TP53 greatly suggests that the first checkpoint G1/S is compromised allowing unrestrained cells freely entering in the next S-phase.

We then examined the cyclins, putative markers of cell cycle phases and regulatory subunits of the cyclin-dependent kinases (cdks), whose levels peak the specific stages of the cell cycle. The first cyclin level examined was cyclin D1, which is maximally expressed in mid-to-late G1 phase and its kinase activity, elicited by binding with cdk4 (predominantly cyclin D1/cdk4 complex), is up-regulated in cancer cells[30]. As shown in Figure 6, treating cells for up to $72 \mathrm{~h}$ with 10-100 
$\mu \mathrm{M}$ ZOL resulted in a marked decrease of cyclin D1 in EGI-1 cells and only at higher concentrations in TFK-1. We further verified the status of $\mathrm{p} 27^{\mathrm{KIP} 1}$ whose function is to bind to cyclin D either alone, or when complexed to its catalytic subunit cdk4. In this way, p27 ${ }^{\text {Kip1 }}$ inhibits the catalytic activity of cdk4, preventing cdk4 from adding phosphate residues to $\mathrm{pRb}$ protein. Increased levels of the p2 $7^{\mathrm{Kip} 1}$ protein typically cause cells to arrest in the G1 phase of the cell cycle. Upon ZOL treatment a dose-dependent decrease in the level of p27 inhibitor was observed in both cell lines, more evident in EGI-1 cells. The p16 ${ }^{\mathrm{INK} 4 \mathrm{~A}}$, which shares with $\mathrm{pRb}$ and p27 a regulatory role at G1/S checkpoint, is frequently mutated or deleted in a wide variety of tumors, in particular in bile duct cancers, and not expressed in the cholangiocarcinoma cell lines used in this work[31, 32]. In several human malignancies, the loss, mutation or silencing of the gene encoding the CDK4 inhibitor $\mathrm{p} 16^{\mathrm{INK} 4 \mathrm{a}}$ hyperactivates the kinase activity of CDK4[3335]. Next, cyclin A expression is important for progression through the $S$ phase and $G 2 / M$ transition[36]. Cyclin A, in contrast to cyclin D1, showed significant increases in both cell lines following cell exposed to ZOL and thus indicating a slow-down and/or an arrest in the S-phase. Moreover, cyclin B1, in complex with cdk1, functions as an M-phase kinase[37]. No changes of cyclin B1 level were observed in both cell lines except a distinct drop at 50 $\mathrm{MM}$ ZOL in EGI-1 cells. Finally, we analyzed the phospho-histone H3, a marker of cromatin condensation. The Western blotting analysis indicated that ZOL increases the level of this M-phase marker. This increment was in agreement with the increased level of cyclins A.

These findings on the significant changes in the levels of specific cell cycle cyclins and inhibitors confirm the results observed with cell-cycle analysis and further indicate a ZOL interference with the cell cycle progression machinery at the putative S-phase check point. 


\subsection{Apoptosis assessment}

As shown in Figure 4, in both cholangiocarcinoma cell lines, ZOL treatment did not induce any apoptotic sub-G1 peak. In order to confirm the absence of apoptotic death, we examined the morphological and biochemical features of apoptosis. The cells were stained with Hoechst 33342 and propidium iodide. Condensed chromatin or apoptotic cells were rarely seen in all the cell populations studied: only $8-12 \%$ of control cells and of tested cells treated with the drug up to $25 \mu \mathrm{M}$ were homogeneously and intensively stained by propidium iodide indicating cell death. None evident characteristics of apoptosis (such as cell shrinkage, apoptotic bodies, cytoplasmic blebs, chromatin collapse into patches and dense spheres) were observed. Only when EGI-1 cells were treated with $50 \mu \mathrm{M}$, approximately $10 \%$ of cells showed some apoptotic characteristics (not shown).

We then investigated the occurrence of apoptosis by biochemical criteria such as activation of caspases or presence of cleavage products of their substrates. Figure 6A shows that none effect on caspase-3 activation occurred after cells exposure to ZOL. Moreover, the drug did not induce cleavage of PARP, a key enzyme in the apoptotic cascade and substrate of active caspase-3.

To investigate if the cell-death resistance is specific to zoledronic acid, we evaluate the effect of staurosporine, gemcitabine and nitrogen (pamidronate) and a non-nitrogen (clodronate) containing bisphosphonate on caspase-3 and PARP activation. Experiments using the abovementioned drugs indicated that staurosporine on EGI-1 cells and gemcitabine on both cell lines were able to induce caspase-3 and PARP activation. In contrast and similarly to ZOL, pamidronate and clodronate did not activate caspase-3 nor PARP (Figure 6B).

The analysis of the expression of anti- versus pro-apoptotic proteins indicated that untreated TFK-1 cells markedly express the anti-apoptotic $\mathrm{Bcl}-\mathrm{xL}$ and at greater extent the pro-apoptotic 
Bax protein, accordingly to literature data[38, 39]. As shown in Figure 6C, in TFK-1 cells ZOL treatment significantly affected the balance of anti-apoptotic versus pro-apoptotic proteins; it is also interesting to note the marked decrease of Bax coupled to the increasing concentrations of ZOL. Moreover, in EGI-1 cells ZOL treatment did not affect the ratio of Bcl-xL/Bax, already shifted versus the anti-apoptotic Bcl-xL protein.

We then addressed the question whether the observed apoptosis resistance of S-phase arrested cells were associated to high expression of HSP27. HSP27, a powerful chaperone, is a stress protein induced in response to a variety of insults including oncogenic transformation and chemotherapic agents. Its expression allows/helps tumor cells to survive otherwise lethal conditions by counteracting at multiple control points of the apoptotic pathway and therefore increasing the tumorigenic potential of cancer cells[40]. As shown in Figure 6C, constitutive expression of HSP27 was clearly evident in untreated TFK-1 cells; however, ZOL treatment did not affect its expression. In contrast, in EGI-1 cells HSP27 was not present and ZOL treatment did not induce its expression. 


\section{Discussion}

Despite recent improvements in surgery and the development of different regimens of multidrug chemotherapy over the past 25 years, survival of patients suffering from cholangiocarcinoma remains around 5 to $20 \%$ after 5 years[41, 42]. The poor prognosis of cholangiocarcinoma[2] warrants new therapeutic strategies to improve the overall rate of survival, especially in high-risk subgroups.

In the present study, we examined the commonly used biphosphonate molecule ZOL, because of its high biological activity in inducing inhibition of proliferation and apoptosis in several cancer cell lines[20]. We here reported that ZOL, the most potent nitrogen containing BP, causes antiproliferative effects in EGI-1 and TFK-1 cholangiocarcinoma cells. ZOL inhibited cell growth in dose-dependent manner in both cell lines tested. The $\mathrm{IC}_{50}$ range from 17 to $37 \mu \mathrm{M}$ for EGI-1 and TFK-1 cells, respectively. The co-treatment with GGOH prevented morphological changes and growth inhibition induced by zoledronate suggesting that a replenishing of protein geranygeranylation could overcome the FPP synthase-block. Furthemore, ZOL-induced inhibition of Rap1A prenylation was reversed by GGOH, suggesting that ZOL-induced inhibition of proliferation is mediated via inhibition of the mevalonate pathway also in cholangiocarcinoma cells.

The ability to form a colony from a single cell, may be seen as a surrogate of the invasive ability of the tumor cell[43]. Interestingly, in cholangiocarcinoma cells this ability is markedly impaired at $8 \mu \mathrm{M}$ ZOL, a concentration 2-4 fold lower than those seen in the MTT assay. It should be noted that cells, exposed up to $\mathrm{IC}_{50} \mathrm{ZOL}$ for $72 \mathrm{~h}$, following drug removal later on resume their growth thus indicating the reversibility of the inhibition. In our opinion, this property of ZOL suggests its 
potential use, in cholangiocarcinoma affected patients, as effective adjuvant therapy for metastasis and disease relapse.

The anti-proliferative effect of ZOL was associated with a change of cell distribution in the cell cycle phases as indicated by the accumulation and arrest of cancer cells in S-phase. This observation is in accordance with previously studies on different types of tumor cells, all suggesting arrest of ZOL-treated cells in the S-phase[23-27]. To date, however, the details of the molecular mechanism of cell cycle arrest involved remain obscure. The G1/S checkpoint is often compromised in many tumor cells due to mutation or deletion of tumor suppressor genes including $\mathrm{pRb}$ and TP53[44]. Several studies conducted so far have assessed the deregulation of the pRb-pathway components in various human tumors and cell-lines, provided these pathway alterations play an obligatory role in tumorigenesis. The concomitant high level of $\mathrm{p} 27^{\mathrm{KIP} 1}$ is required for the assembly of active cyclin D1-CDK4[45]. In the presence of ZOL in both cholangiocarcinoma cell lines a reduced expression of the inhibitor $\mathrm{p} 27^{\mathrm{Kip} 1}$ and a concomitant suppression of the cell cycle promoter D1 were observed. The dual suppression of cyclin D1 and $\mathrm{p} 27^{\mathrm{KIP} 1}$, two critical control molecules, and the persistence of $\mathrm{pRb}$ in the hyperphosphorylated status should allow the cells to freely enter in the S-phase and to accelerate through the cell cycle[45]. The dose-dependent accumulation of cells in the S-phase, however, suggests an arrest at the S-phase checkpoint. Moreover, the observed ZOL dose-dependent increase of cyclin A expression is consistent with a large fraction of cells accumulated in the S-phase. Massive DNA repair should presumably allow slow down or arrest of S-phase progression. The concomitant high level of cyclin B1, putative marker of M phase, was not significantly affected by ZOL, thus indicating that this phase has not been passed by the cells.

Taken together our results on phase distribution of cells, expression of cyclin proteins and their regulators $\mathrm{pRb}$ and $\mathrm{p} 27^{\mathrm{KIP} 1}$ suggest that ZOL treatment on cholangiocarcinoma cells do not 
induce G1/S arrest, as already seen in other tumor cells[26, 46]. It determines an arrest of cells in the S-phase without an accumulation of cells in the G2-phase and absence of apoptosis induction. Several studies have described induction of apoptosis (caspase-dependent and -independent) by the administration of ZOL to cancer cells. For example, in breast cancer ZOL decreased the cell growth in a dose-dependent manner, this effect being ascribed to the concomitant BP-induced increase in cell apoptosis[47]. Similarly, it was reported that ZOL was able to induce apoptotic death in several pancreatic cells achieving 35-90\% of apoptotic cells in the treated groups. Independently of the TP53 and pRb status, in osteosarcoma cells, it was recently described a ZOL induction of atypical apoptosis independent of caspase activation and involving the mitochondrial pathway, in particular the translocation to the nucleus of the apoptosis-inducing factor (AIF)[27]. Our data support the notion that ZOL could inhibit cholangiocarcinoma cell proliferation by inducing cell accumulation/arrest in the S-phase but without inducing apoptosis. We have found that, subsequent to ZOL treatment both TFK-1 and EGI-1 cells are prevented to activate the apoptotic pathway as shown by the lack of sub-G1 peak, and the absence of caspase 3 cleaved fragment. This outcome was confirmed by lack of morphological features of apoptosis. This lack of apoptosis was not specific to ZOL treatment since similar results were obtained by using pamidronate (N-BP) or clodronate (BP). It worth to note that these cells are quite resistant to cell death as shown by moderate caspase- 3 activation observed in the presence of a high concentration of staurosporine (a classical inducer of apoptosis in several cells). Interestingly, in staurosporine-exposed PC-3 cells the overexpression of anti-apoptotic protein Bcl-xL was found to be associated with resistance because of abrogation of cytochrome c release to the cytosol[48]. Discrepant observations about the ability of biphosphonates to induce apoptosis was reported by Lee et al.[49]. These authors showed that reduction in prostate cell growth was mainly mediated by cell cycle prolongation. Other two papers related to breast and lung cancer[50,51] showed 
that ZOL administration inhibited cancer cell proliferation, although only a minor fraction of cells (less than $20 \%$ in the case of lung cancer) entered in the apoptotic process.

Some mechanisms have been proposed to explain the potential refractory of tumor cells to activate the apoptotic program following ZOL treatment. For instance, the failure of ZOL to induce apoptosis is linked to the high levels of anti-apoptotic signals such as Bcl-2 proteins family. Interestingly, some authors have hypothesised that high concentrations of antiapoptotic proteins, such as Bcl-2 proteins, within the biliary tree could play a key role in the development of cholangiocarcinoma[38, 39]. A few years ago it was reported that the enhanced Bcl-2 expression alters the threshold for apoptosis in a cholangiocarcinoma cell line[52]. Moreover, Bcl-2 over-expression could protect myeloma cells against ZOL-induced apoptosis but not against cytostasis[53]. In agreement with this report, our results show that Bcl-xL, an antiapoptotic member of the Bcl-2 family proteins, is significantly expressed in both cholangiocarcinoma cell lines, while the pro-apoptotic Bax protein is largely expressed only in TFK-1 cells. ZOL treatment reverted the ratio between pro-apoptotic Bax versus anti-apoptotic Bcl-xL in TFK-1 cells, meanwhile in EGI-1 cells this ratio, already shifted versus the antiapoptotic component, was unaffected by the drug.

Our results support the plausible anti-apoptotic role of the Bcl-xL protein to contrast the cytotoxic effect of ZOL as observed by other authors[38]. As already indicated above, Bcl-xL overexpression is one of the mediator of resistance to staurosporine-induced apoptosis[48]. Recently, it was shown that Bcl-xL overexpression protects from apoptosis induced by HMGCoA reductase inhibitors (simvastatin) in murine tubular cell line[54]. Moreover, antisense Bcl$\mathrm{xL}$ down-regulation has been reported to induce apoptosis in colorectal cancer cells[55]. Taken together, these reports and our results suggest that the expression of Bcl-xL protein might prevent cellular apoptosis, and confirm, at least in vitro, the resistance of TFK-1 and EGI-1 cells to the 
apoptosis-inducing effects of ZOL. An additional mechanism that emerges from this study and might explain the higher resistance to ZOL exhibited by TFK-1 cells, in comparison to EGI-1 cells $\left(\mathrm{IC}_{50}=37\right.$ vs 17$)$, could be linked to the constitutive expression of the antiapoptotic HSP27 protein. This remark is suggested by the known role of HSP27 in conferring chemotherapy resistance, in inhibiting apoptotic cell death, and facilitating tumor progression[56, 57]. Our previous results suggest that HSP27 could be also a prognostic factor in cholangiocarcinoma[58] In conclusion, our study provides the first evidence that ZOL elicits a direct inhibitory action on the proliferation of cholangiocarcinoma cells. The cell-cycle alteration induced by ZOL, i.è. cell accumulation/arrest in S-phase, was confirmed by changes in the level of cyclins D1 and A, and of regulators $\mathrm{p} 27^{\mathrm{KIP} 1}$ and $\mathrm{pRb}$. ZOL therefore, could represent a reliable chemotherapeutic agent able to sensitize cells to cytotoxic agents and/or radiations.

Our data indicate that a dose of $10-50 \mu \mathrm{M}$ ZOL is required for a significant cell cycle arrest in cholangiocarcinoma cells. This range of concentrations, however, may preclude ZOL to be used as monotherapy in cholangiocarcinoma, thus making mandatory the need to investigate differently active molecules to associate with ZOL, in order to obtain a synergistic therapeutic improvement and minimizing, in the same time, the side effects. 


\section{Acknowledgements}

This study was supported by RE.GA.STR project (Programma di Ricerca Regione-Università 2007-2009, Emilia-Romagna, Italy) and FIL grants from MIUR (Rome, Italy). Silvia Desenzani was supported by a fellowship from Fondazione Cariparma, Parma, Italy. We thank Simona Stefàno for her precious technical assistance. 


\section{References}

[1] Khan SA, Thomas HC, Davidson BR, Taylor-Robinson SD. Cholangiocarcinoma. Lancet 2005;366:1303-14.

[2] Blechacz B, Gores GJ. Cholangiocarcinoma: advances in pathogenesis, diagnosis, and treatment. Hepatology (Baltimore, Md 2008;48:308-21.

[3] Poplin E, Roberts J, Tombs M, Grant S, Rubin E. Leucovorin, 5-fluorouracil, and gemcitabine: a phase I study. Invest New Drugs 1999;17:57-62.

[4] Pazdur R, Royce ME, Rodriguez GI, Rinaldi DA, Patt YZ, Hoff PM, et al. Phase II trial of docetaxel for cholangiocarcinoma. Am J Clin Oncol 1999;22:78-81.

[5] Thongprasert S, Napapan S, Charoentum C, Moonprakan S. Phase II study of gemcitabine and cisplatin as first-line chemotherapy in inoperable biliary tract carcinoma. Ann Oncol 2005;16:279-81.

[6] Dive C. Avoidance of apoptosis as a mechanism of drug resistance. J Intern Med Suppl 1997;740:139-45.

[7] Eastman A. Apoptosis: a product of programmed and unprogrammed cell death. Toxicol Appl Pharmacol 1993;121:160-4.

[8] Huether A, Hopfner M, Baradari V, Schuppan D, Scherubl H. Sorafenib alone or as combination therapy for growth control of cholangiocarcinoma. Biochemical pharmacology 2007;73:1308-17. 
[9] Hannun YA. Apoptosis and the dilemma of cancer chemotherapy. Blood 1997;89:1845-53.

[10] Romani AA, Soliani P, Desenzani S, Borghetti AF, Crafa P. The associated expression of Maspin and Bax proteins as a potential prognostic factor in intrahepatic cholangiocarcinoma. BMC cancer 2006;6:255.

[11] Clezardin P. Anti-tumour activity of zoledronic acid. Cancer Treat Rev 2005;31 Suppl 3:1-8.

[12] Aviles A, Nambo MJ, Neri N, Castaneda C, Cleto S, Huerta-Guzman J. Antitumor effect of zoledronic acid in previously untreated patients with multiple myeloma. Med Oncol 2007;24:227-30.

[13] Gralow J. Evolving role of bisphosphonates in women undergoing treatment for localized and advanced breast cancer. Clin Breast Cancer 2005;5 Suppl:S54-62.

[14] Hoesl CE, Altwein JE. Biphosphonates in advanced prostate and renal cell cancer-current status and potential applications. Urol Int 2006;76:97-105.

[15] Melisi D, Caputo R, Damiano V, Bianco R, Veneziani BM, Bianco AR, et al. Zoledronic acid cooperates with a cyclooxygenase-2 inhibitor and gefitinib in inhibiting breast and prostate cancer. Endocr Relat Cancer 2005;12:1051-8.

[16] Rogers MJ, Gordon S, Benford HL, Coxon FP, Luckman SP, Monkkonen J, et al. Cellular and molecular mechanisms of action of bisphosphonates. Cancer 2000;88:2961-78. 
[17] Rodan GA. Bone mass homeostasis and bisphosphonate action. Bone 1997;20:1-4.

[18] Sonnemann J, Eckervogt V, Truckenbrod B, Boos J, Winkelmann W, van Valen F. The bisphosphonate pamidronate is a potent inhibitor of Ewing's sarcoma cell growth in vitro. Anticancer Drugs 2003;14:767-71.

[19] Mackie PS, Fisher JL, Zhou H, Choong PF. Bisphosphonates regulate cell growth and gene expression in the UMR 106-01 clonal rat osteosarcoma cell line. British journal of cancer 2001;84:951-8.

[20] Russell RG. Bisphosphonates: mode of action and pharmacology. Pediatrics 2007;119 Suppl 2:S150-62.

[21] Toyras A, Ollikainen J, Taskinen M, Monkkonen J. Inhibition of mevalonate pathway is involved in alendronate-induced cell growth inhibition, but not in cytokine secretion from macrophages in vitro. Eur J Pharm Sci 2003;19:223-30.

[22] Luckman SP, Hughes DE, Coxon FP, Graham R, Russell G, Rogers MJ. Nitrogencontaining bisphosphonates inhibit the mevalonate pathway and prevent posttranslational prenylation of GTP-binding proteins, including Ras. J Bone Miner Res 1998;13:581-9.

[23] Forsea AM, Muller C, Riebeling C, Orfanos CE, Geilen CC. Nitrogen-containing bisphosphonates inhibit cell cycle progression in human melanoma cells. British journal of cancer 2004;91:803-10.

[24] Iguchi T, Miyakawa Y, Saito K, Nakabayashi C, Nakanishi M, Saya H, et al. Zoledronate-induced $S$ phase arrest and apoptosis accompanied by DNA damage 
and activation of the ATM/Chk1/cdc25 pathway in human osteosarcoma cells. International journal of oncology 2007;31:285-91.

[25] Kubista B, Trieb K, Sevelda F, Toma C, Arrich F, Heffeter P, et al. Anticancer effects of zoledronic acid against human osteosarcoma cells. J Orthop Res 2006;24:1145-52.

[26] Kuroda J, Kimura S, Segawa H, Sato K, Matsumoto S, Nogawa M, et al. p53independent anti-tumor effects of the nitrogen-containing bisphosphonate zoledronic acid. Cancer Sci 2004;95:186-92.

[27] Ory B, Blanchard F, Battaglia S, Gouin F, Redini F, Heymann D. Zoledronic acid activates the DNA S-phase checkpoint and induces osteosarcoma cell death characterized by apoptosis-inducing factor and endonuclease-G translocation independently of p53 and retinoblastoma status. Mol Pharmacol 2007;71:333-43.

[28] Sewing L, Steinberg F, Schmidt H, Goke R. The bisphosphonate zoledronic acid inhibits the growth of HCT-116 colon carcinoma cells and induces tumor cell apoptosis. Apoptosis 2008;13:782-9.

[29] Olivier M, Eeles R, Hollstein M, Khan MA, Harris CC, Hainaut P. The IARC TP53 database: new online mutation analysis and recommendations to users. Human mutation 2002;19:607-14.

[30] Sherr CJ. Cancer cell cycles. Science (New York, NY 1996;274:1672-7.

[31] Caca K, Feisthammel J, Klee K, Tannapfel A, Witzigmann H, Wittekind C, et al. Inactivation of the INK4a/ARF locus and p53 in sporadic extrahepatic bile duct 
cancers and bile tract cancer cell lines. Int J Cancer 2002;97:481-8.

[32] Tannapfel A, Benicke M, Katalinic A, Uhlmann D, Kockerling F, Hauss J, et al. Frequency of p16(INK4A) alterations and K-ras mutations in intrahepatic cholangiocarcinoma of the liver. Gut 2000;47:721-7.

[33] Borg A, Sandberg T, Nilsson K, Johannsson O, Klinker M, Masback A, et al. High frequency of multiple melanomas and breast and pancreas carcinomas in CDKN2A mutation-positive melanoma families. Journal of the National Cancer Institute 2000;92:1260-6.

[34] Nobori T, Miura K, Wu DJ, Lois A, Takabayashi K, Carson DA. Deletions of the cyclin-dependent kinase-4 inhibitor gene in multiple human cancers. Nature 1994;368:753-6.

[35] Spruck CH, 3rd, Gonzalez-Zulueta M, Shibata A, Simoneau AR, Lin MF, Gonzales F, et al. p16 gene in uncultured tumours. Nature 1994;370:183-4.

[36] Pagano M, Pepperkok R, Verde F, Ansorge W, Draetta G. Cyclin A is required at two points in the human cell cycle. The EMBO journal 1992;11:961-71.

[37] Dunphy WG, Brizuela L, Beach D, Newport J. The Xenopus cdc2 protein is a component of MPF, a cytoplasmic regulator of mitosis. Cell 1988;54:423-31.

[38] Okaro AC, Deery AR, Hutchins RR, Davidson BR. The expression of antiapoptotic proteins Bcl-2, Bcl-X(L), and Mcl-1 in benign, dysplastic, and malignant biliary epithelium. J Clin Pathol 2001;54:927-32. 
[39] Okaro AC, Fennell DA, Corbo M, Davidson BR, Cotter FE. Pk11195, a mitochondrial benzodiazepine receptor antagonist, reduces apoptosis threshold in Bcl-X(L) and Mcl-1 expressing human cholangiocarcinoma cells. Gut 2002;51:55661.

[40] Garrido C, Brunet M, Didelot C, Zermati Y, Schmitt E, Kroemer G. Heat shock proteins 27 and 70: anti-apoptotic proteins with tumorigenic properties. Cell cycle (Georgetown, Tex 2006;5:2592-601.

[41] Patel T. Cholangiocarcinoma. Nat Clin Pract Gastroenterol Hepatol 2006;3:33-42.

[42] Malhi H, Gores GJ. Cholangiocarcinoma: modern advances in understanding a deadly old disease. J Hepatol 2006;45:856-67.

[43] Reddig PJ, Juliano RL. Clinging to life: cell to matrix adhesion and cell survival. Cancer Metastasis Rev 2005;24:425-39.

[44] Bucher N, Britten CD. G2 checkpoint abrogation and checkpoint kinase-1 targeting in the treatment of cancer. British journal of cancer 2008;98:523-8.

[45] Stacey DW. Cyclin D1 serves as a cell cycle regulatory switch in actively proliferating cells. Current opinion in cell biology 2003;15:158-63.

[46] Oades GM, Senaratne SG, Clarke IA, Kirby RS, Colston KW. Nitrogen containing bisphosphonates induce apoptosis and inhibit the mevalonate pathway, impairing Ras membrane localization in prostate cancer cells. The Journal of urology 2003;170:246-52. 
[47] Croucher P, Jagdev S, Coleman R. The anti-tumor potential of zoledronic acid. Breast 2003;12 Suppl 2:S30-6.

[48] Li X, Marani M, Mannucci R, Kinsey B, Andriani F, Nicoletti I, et al. Overexpression of $\mathrm{BCL}-\mathrm{X}(\mathrm{L})$ underlies the molecular basis for resistance to staurosporine-induced apoptosis in PC-3 cells. Cancer research 2001;61:1699-706.

[49] Lee MV, Fong EM, Singer FR, Guenette RS. Bisphosphonate treatment inhibits the growth of prostate cancer cells. Cancer research 2001;61:2602-8.

[50] Li YY, Chang JW, Chou WC, Liaw CC, Wang HM, Huang JS, et al. Zoledronic acid is unable to induce apoptosis, but slows tumor growth and prolongs survival for nonsmall-cell lung cancers. Lung Cancer 2008;59:180-91.

[51] Fromigue O, Lagneaux L, Body JJ. Bisphosphonates induce breast cancer cell death in vitro. $\mathrm{J}$ Bone Miner Res 2000;15:2211-21.

[52] Harnois DM, Que FG, Celli A, LaRusso NF, Gores GJ. Bcl-2 is overexpressed and alters the threshold for apoptosis in a cholangiocarcinoma cell line. Hepatology (Baltimore, Md 1997;26:884-90.

[53] Aparicio A, Gardner A, Tu Y, Savage A, Berenson J, Lichtenstein A. In vitro cytoreductive effects on multiple myeloma cells induced by bisphosphonates. Leukemia 1998;12:220-9.

[54] Blanco-Colio LM, Justo P, Daehn I, Lorz C, Ortiz A, Egido J. Bcl-xL overexpression protects from apoptosis induced by HMG-CoA reductase inhibitors in murine tubular cells. Kidney international 2003;64:181-91. 
[55] Hayward RL, Macpherson JS, Cummings J, Monia BP, Smyth JF, Jodrell DI. Antisense Bcl-xl down-regulation switches the response to topoisomerase I inhibition from senescence to apoptosis in colorectal cancer cells, enhancing global cytotoxicity. Clin Cancer Res 2003;9:2856-65.

[56] Richards EH, Hickey E, Weber L, Master JR. Effect of overexpression of the small heat shock protein HSP27 on the heat and drug sensitivities of human testis tumor cells. Cancer research 1996;56:2446-51.

[57] Mori-Iwamoto S, Kuramitsu Y, Ryozawa S, Mikuria K, Fujimoto M, Maehara S, et al. Proteomics finding heat shock protein 27 as a biomarker for resistance of pancreatic cancer cells to gemcitabine. International journal of oncology 2007;31:1345-50.

[58] Romani AA, Crafa P, Desenzani S, Graiani G, Lagrasta C, Sianesi M, et al. The expression of HSP27 is associated with poor clinical outcome in intrahepatic cholangiocarcinoma. BMC cancer 2007;7:232. 


\section{Legends to Figures}

Figure 1. ZOL inhibits EGI-1 ( $\square$ ) and TFK-1 (匹) cell proliferation. Cells were exposed to ZOL at a concentration ranging from 1 to $1000 \mu \mathrm{M}$. Following $72 \mathrm{~h}$ of incubation growth inhibition was analyzed by MTT assay. Data are presented as mean \pm S.D. of six determinations. A representative experiment is shown. $\mathrm{IC}_{50}$ values and confidential intervals are estimated from data of three independent experiments.

Figure 2. Cholangiocarcinoma cell changes induced after ZOL treatment in the absence and in the presence of $25 \mu \mathrm{M}$ GGOH. (A) Morphology: EGI-1 cells were plated and then treated for $72 \mathrm{~h}$ with vehicle medium, $50 \mu \mathrm{M}$ ZOL, or both $25 \mu \mathrm{M}$ GGOH and $50 \mu \mathrm{M}$ ZOL. (B) Proliferation: Cells were exposed to ZOL at a concentration ranging from 1 to $100 \mu \mathrm{M}$ in the presence ( $\square$ ) and in the absence ( $\square$ ) of $25 \mu \mathrm{M} \mathrm{GGOH}$. Following $72 \mathrm{~h}$ of incubation growth inhibition was analyzed by MTT assay. Data are presented as percentage of control. (C) Western

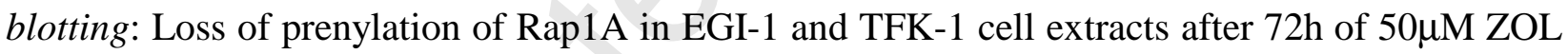
treatment in the presence and in the absence of $25 \mu \mathrm{M} \mathrm{GGOH}$.

Figure 3. Colony formation assay. Influence of $2-32 \mu \mathrm{M} \mathrm{ZOL}$ treatment for ten days on the ability of EGI-1 and TFK-1 cells to form colonies. A representative experiment is shown. The experiment was performed three times yielding similar results.

Figure 4. Flow cytometric analysis of DNA content in EGI-1 and TFK-1 cells, in the absence or in the presence of 10 or $50 \mu \mathrm{M}$ of ZOL for $72 \mathrm{~h}$. The percentage of cells in each cycle phases, in a representative experiment as shown in barchart. Replicated experiments yielded similar results.

Figure 5. Cell cycle regulators and inhibitors. Western blotting detection of TP53, pRb, phosphopRb, p27 ${ }^{\mathrm{KIP} 1}$, cyclin D1, cyclin A, cyclin B1, phospho-HH3 in EGI-1 and TFK-1 cells after 72h 
ZOL treatment. A representative experiment is shown.

Figure 6. Markers of apoptotic pathways. (A) Western blotting detection of caspase-3, PARP after $72 \mathrm{~h}$ ZOL treatment. The sign (\#) indicates the positive control (TFK-1 and EGI-1 cells treated for $72 \mathrm{~h}$ with $100 \mu \mathrm{M}$ of gemcitabine, a known apoptotic inducer) (B) Western blotting detection of caspase-3, PARP after $50 \mu \mathrm{M}$ ZOL, $50 \mu \mathrm{M}$ pamidronate (PAM), $500 \mu \mathrm{M}$ clodronate (CLO), $500 \mathrm{nM}$ staurosporine (STAU) and $100 \mu \mathrm{M}$ gemcitabine (GEM) treatment for $72 \mathrm{~h}$. (C) p38 protein, Phospho-p38 Bcl-xL, Bax, HSP27 in EGI-1 and TFK-1 cells after 72h ZOL treatment. A representative experiment is shown.

Declaration of interest: The authors report no conflicts of interest. The authors alone are responsible for the content and writing of the paper. 
Zoledronic acid (ZOL) induces an S-phase arrest by altering cell cycle regulators and allowing survival of cholangiocarcinoma cells by changing the delicate balance between anti- and proapoptotic proteins.

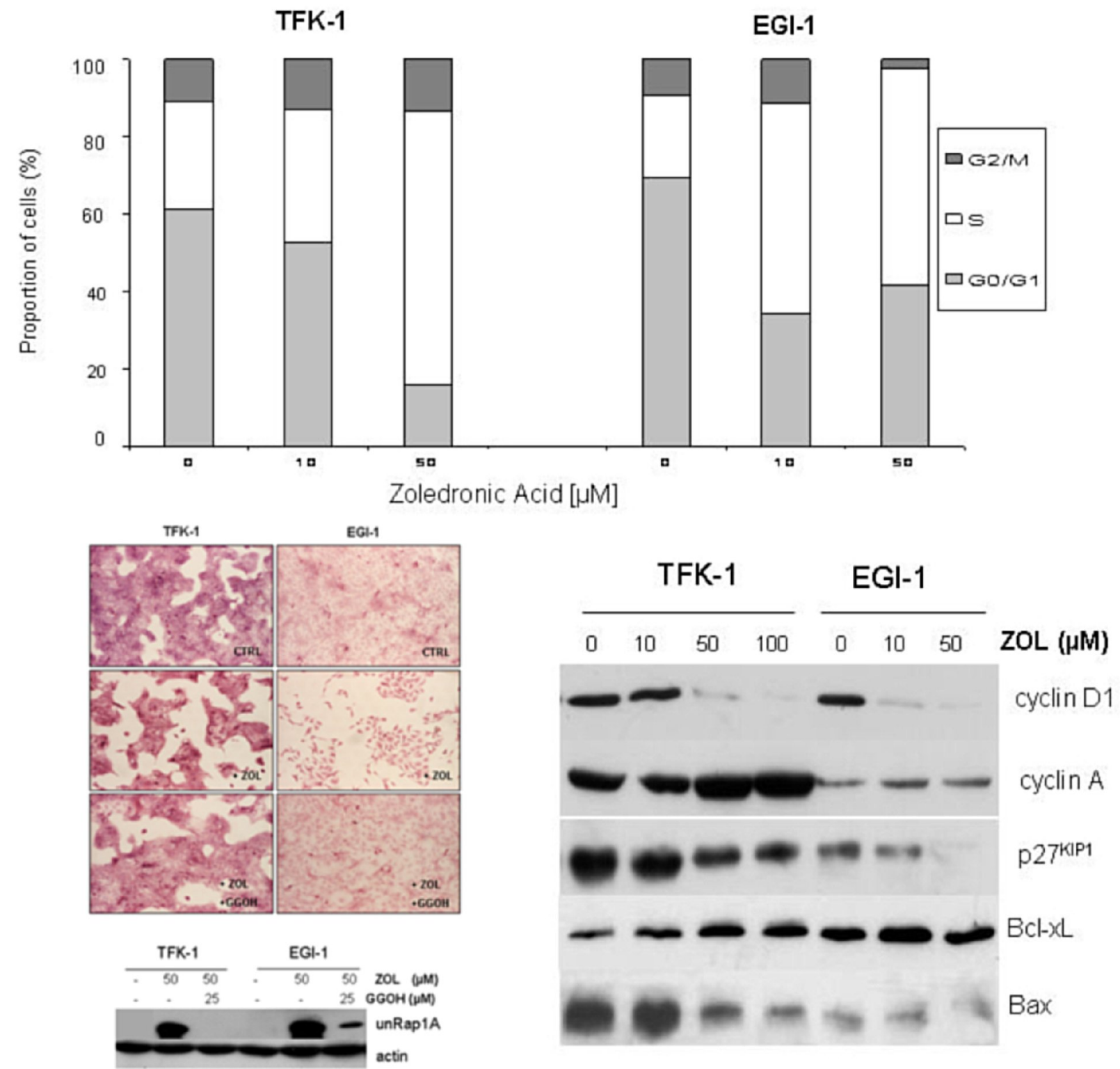




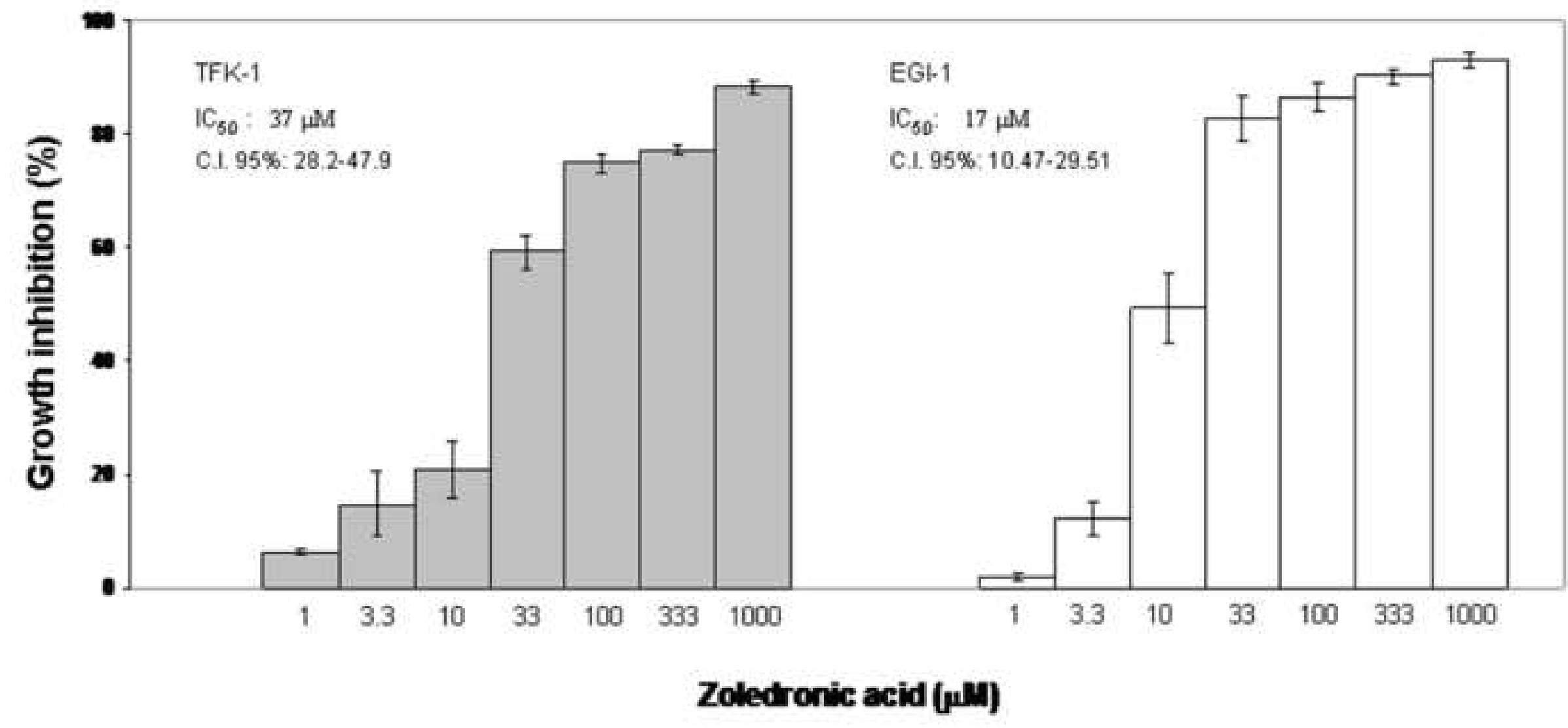


A
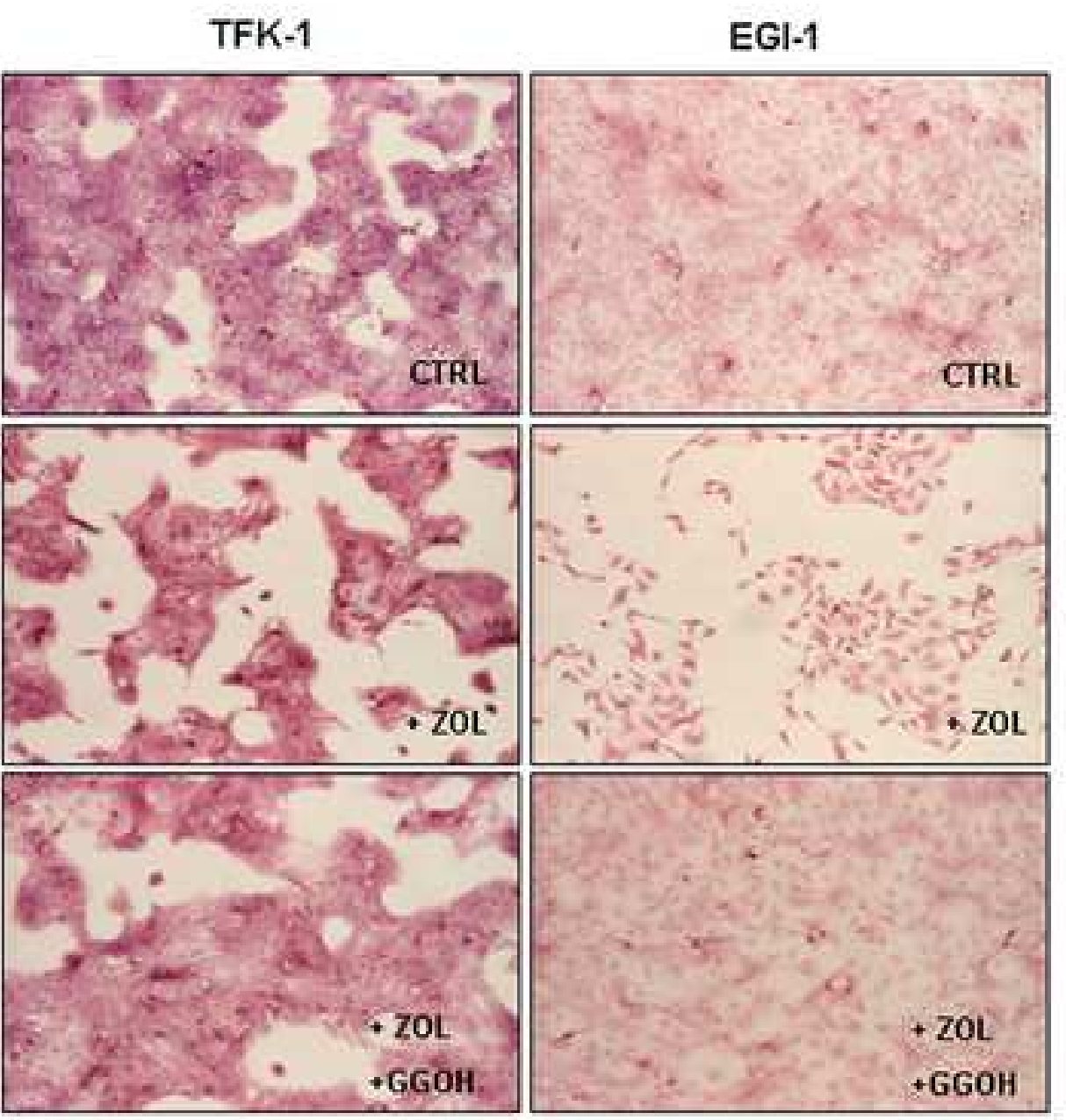

C

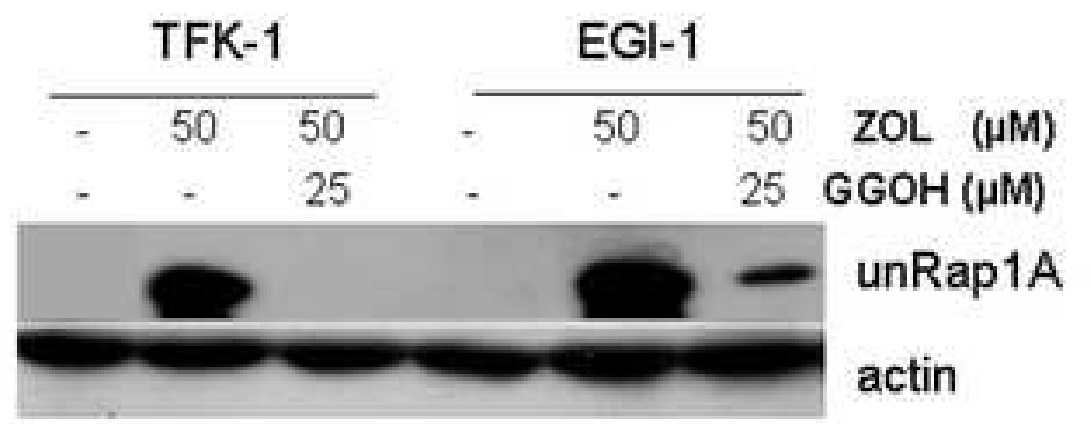

B
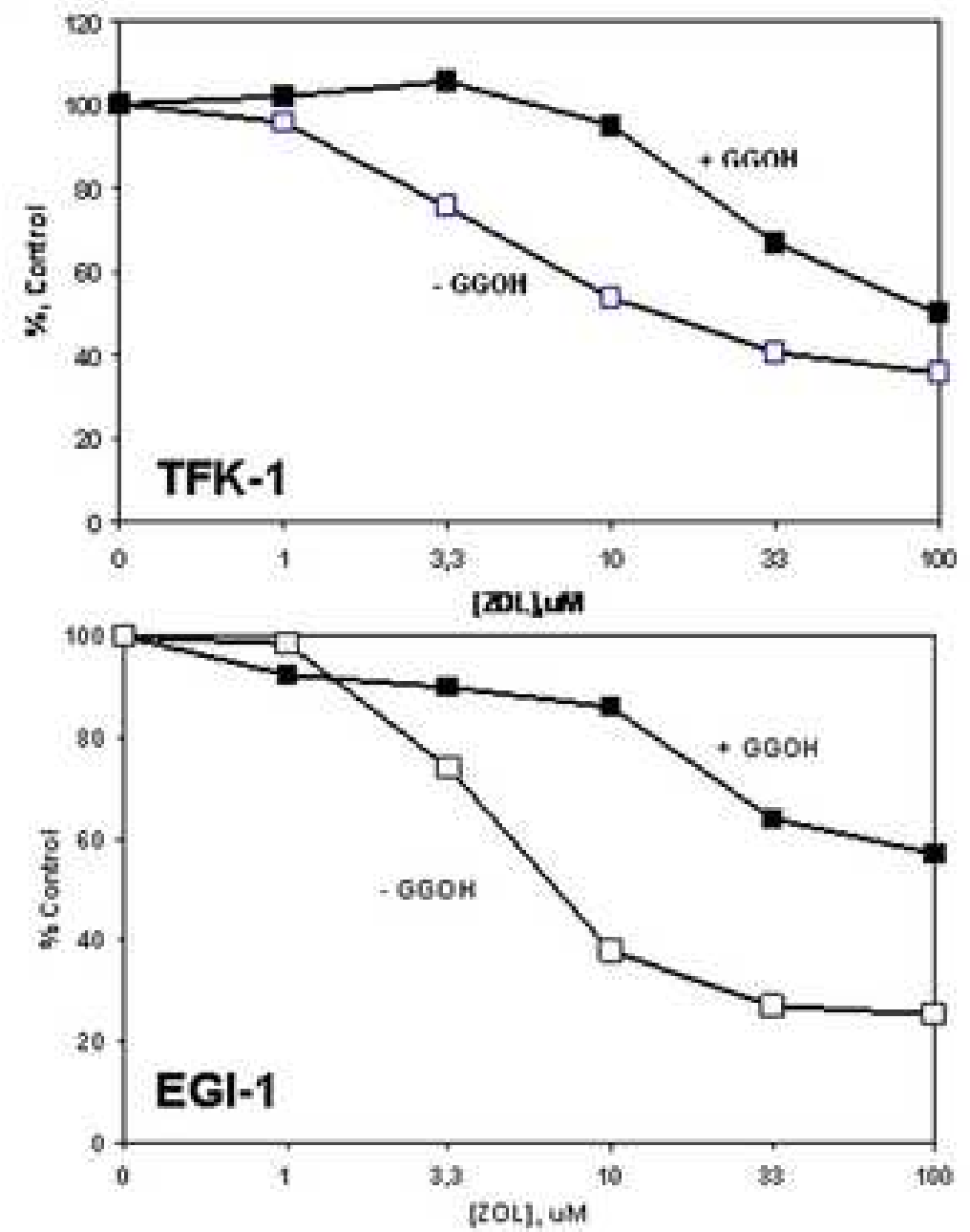

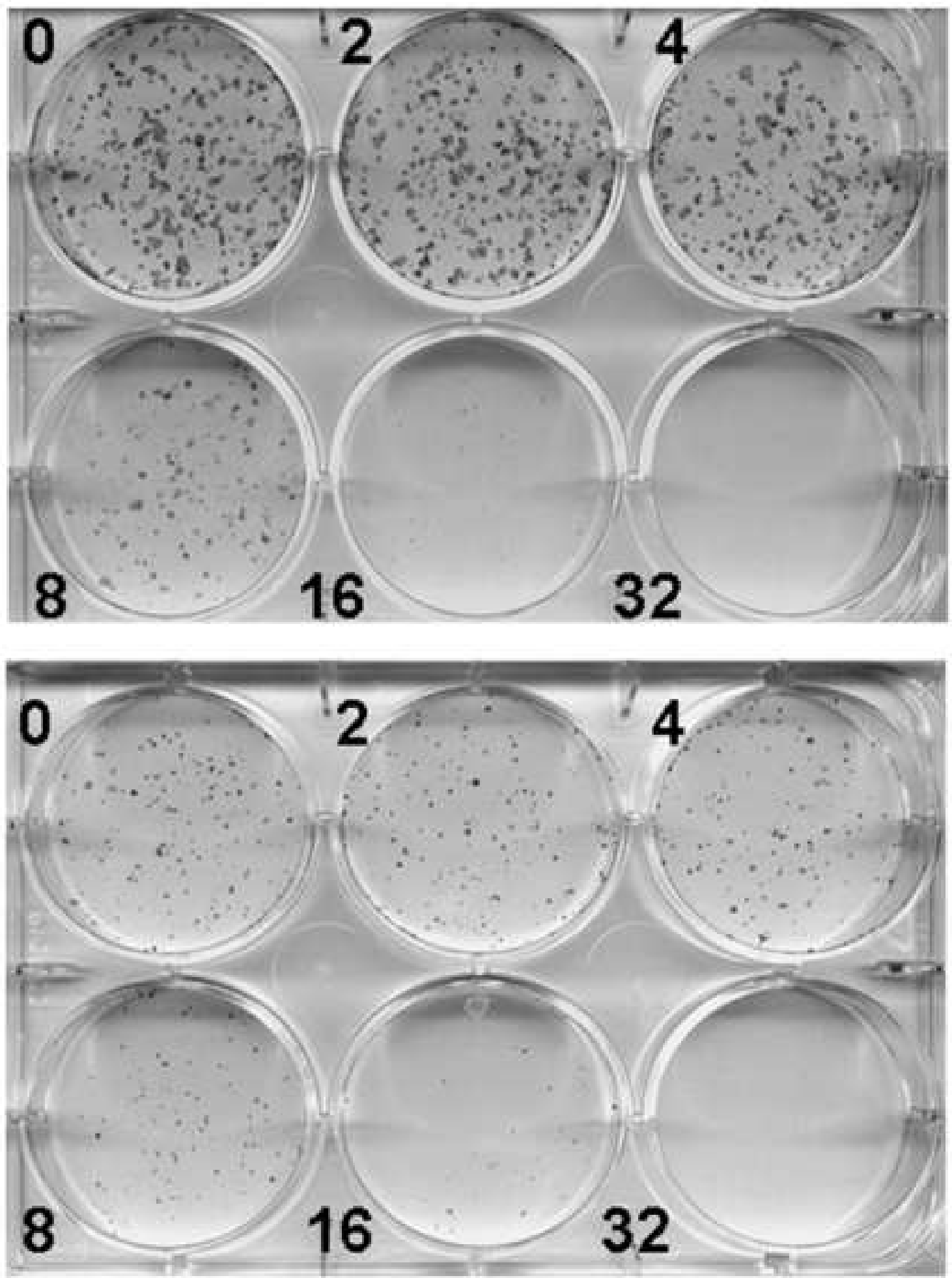

TFK-1
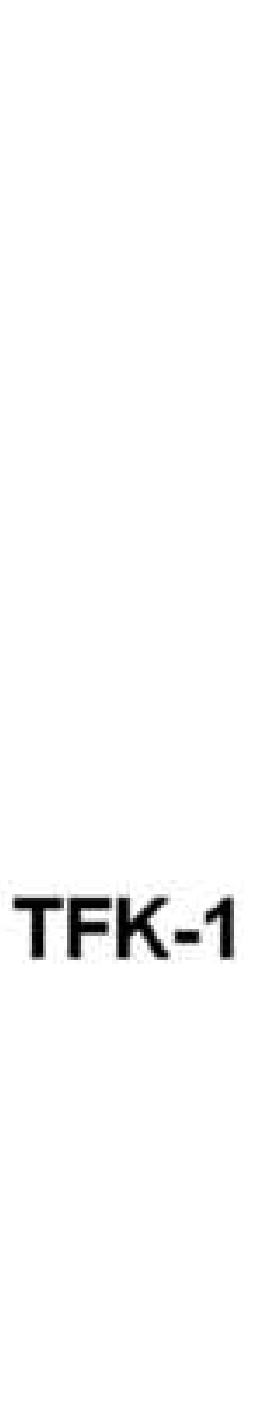

\section{EGI-1

.



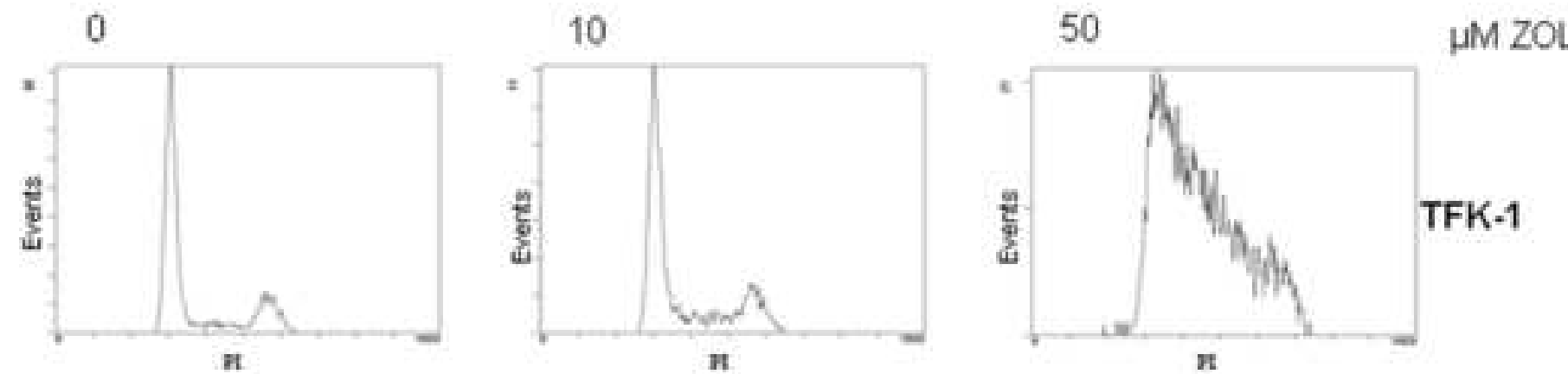

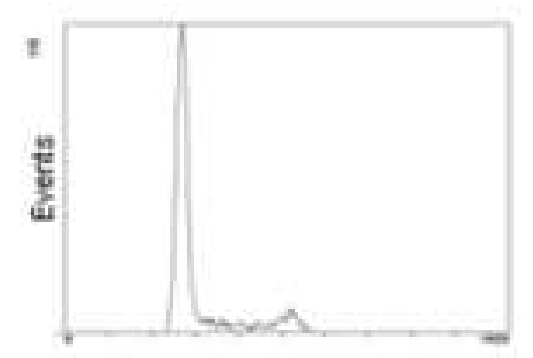

x

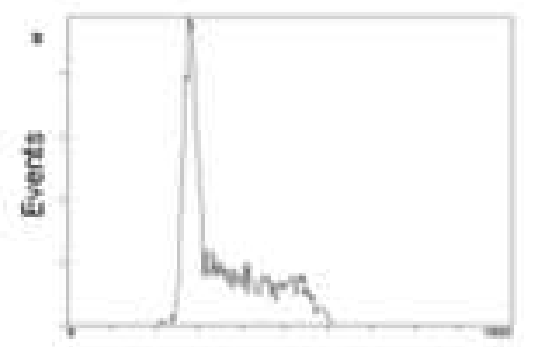

w

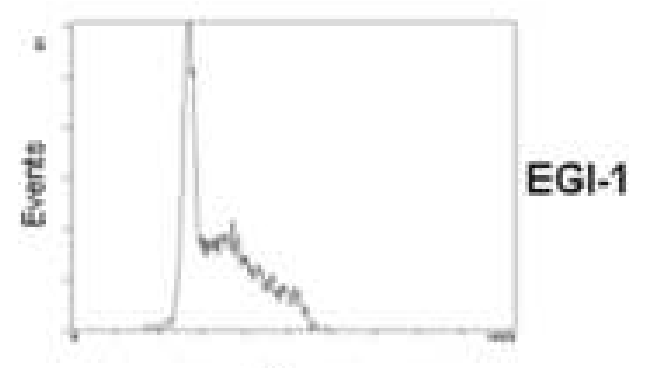

n

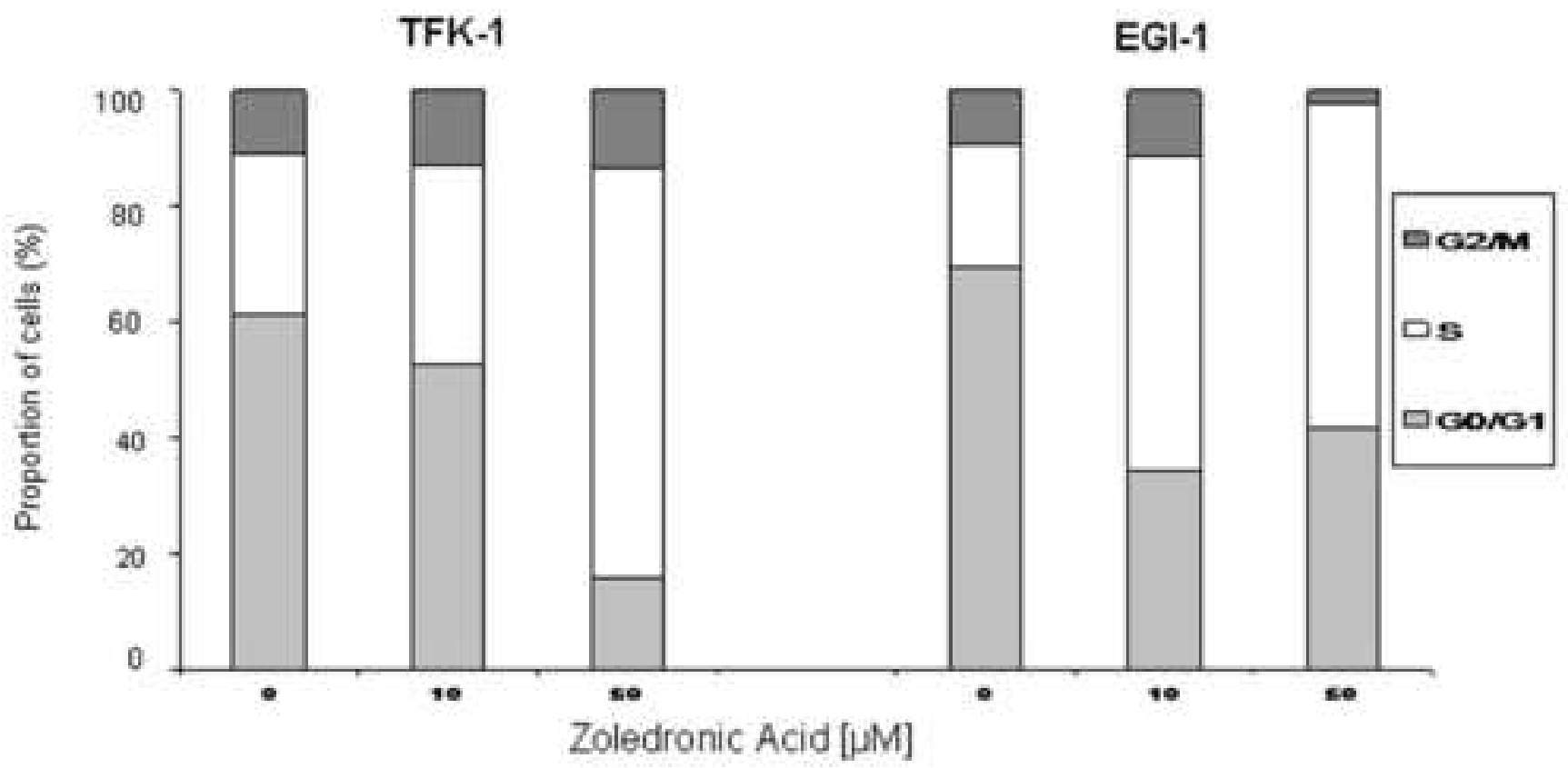

rage 36 or 38 
TFK-1 EGI-1

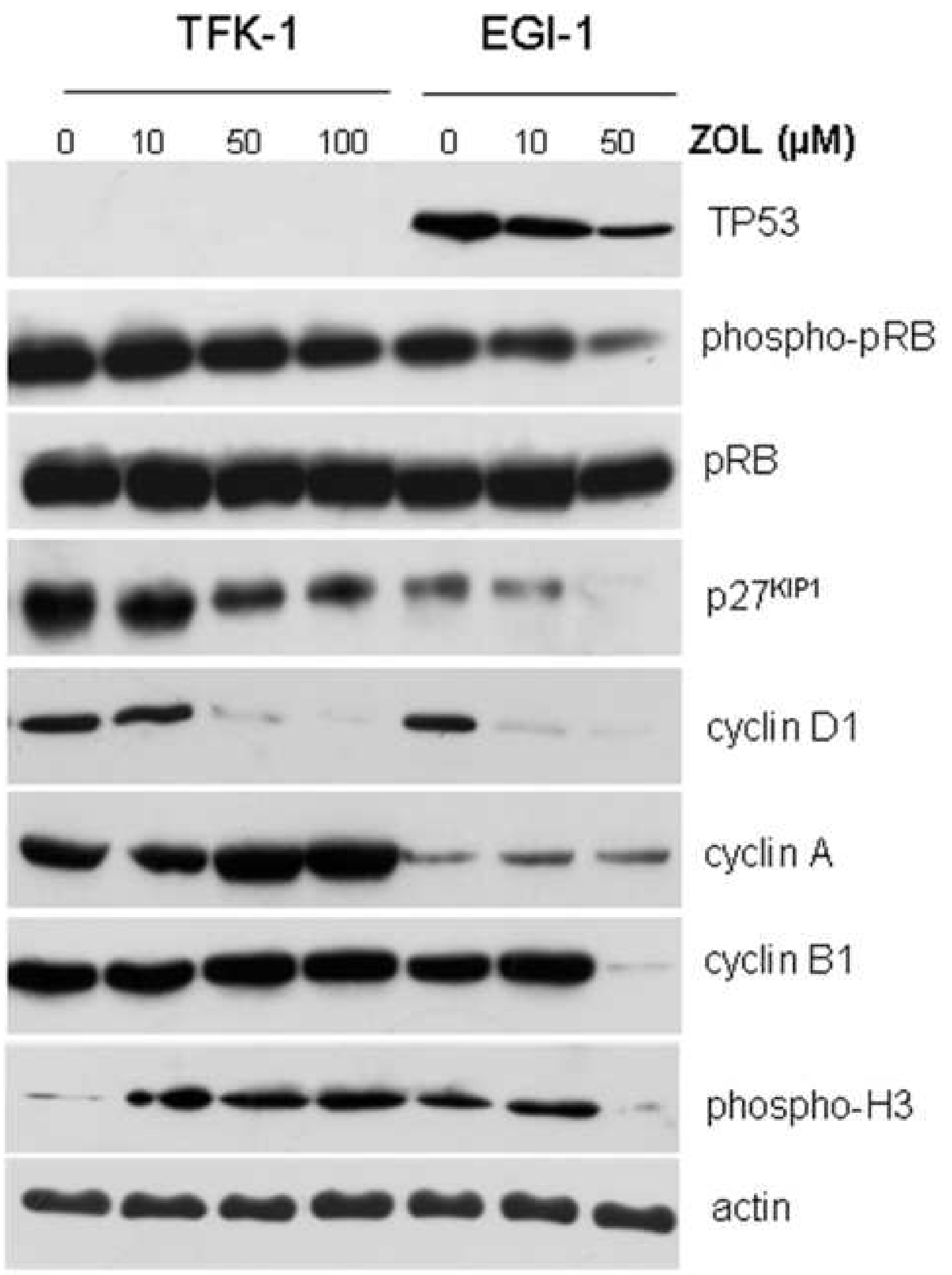


A

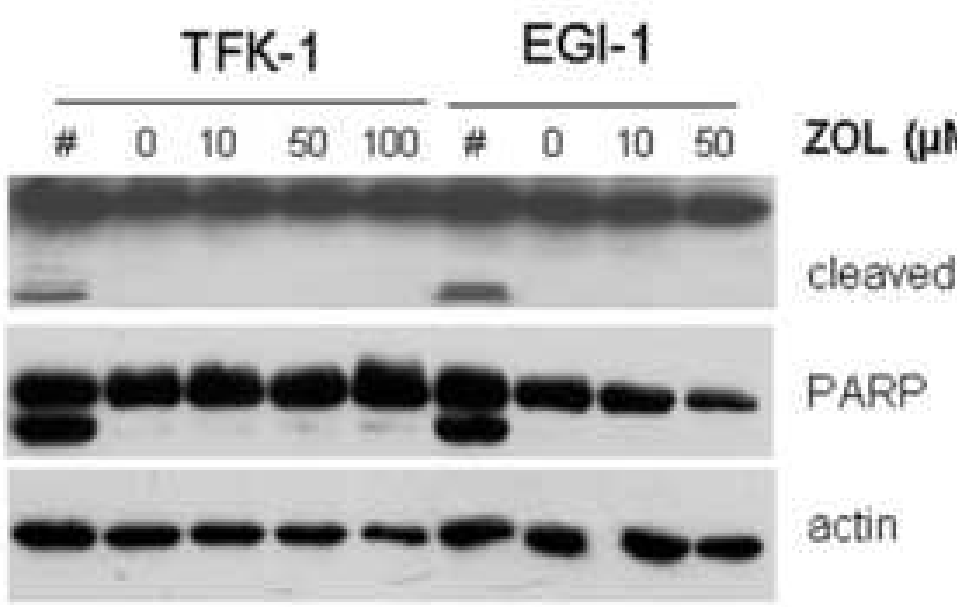

B
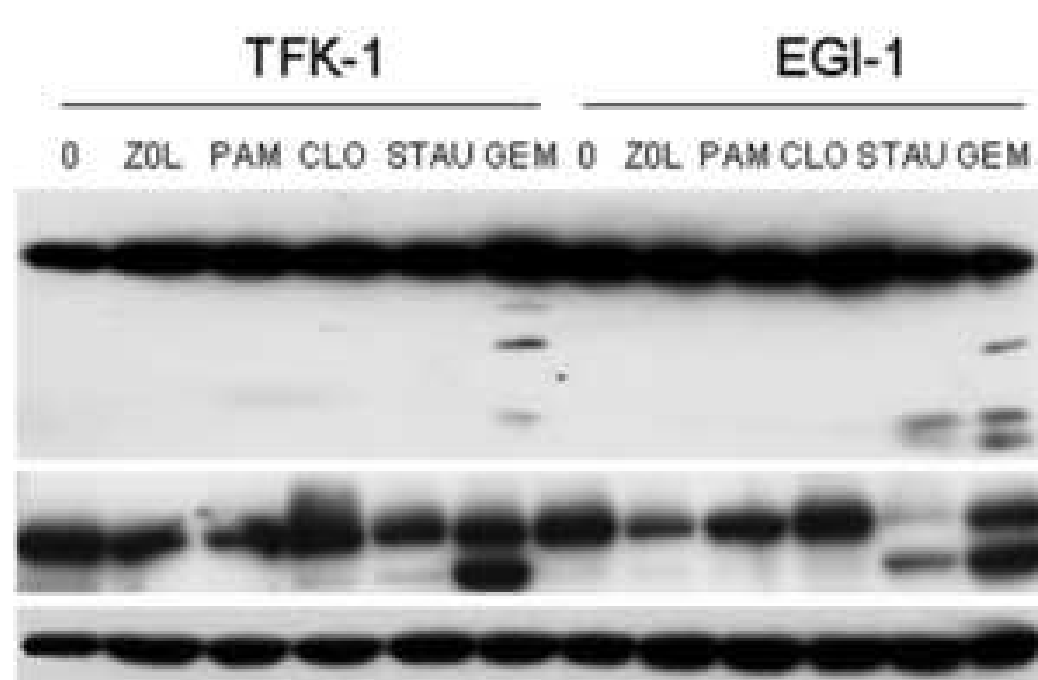

C

$\frac{\text { TFK-1 }}{0 \quad 10 \quad 50 \quad 100}$

$\frac{\text { EGl-1 }}{0.50}$

ZOL $(\mu \mathrm{M})$

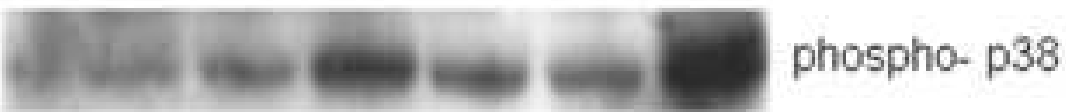

p38

$-\infty-\infty \omega \infty \mathrm{BCl} \times \mathrm{xL}$

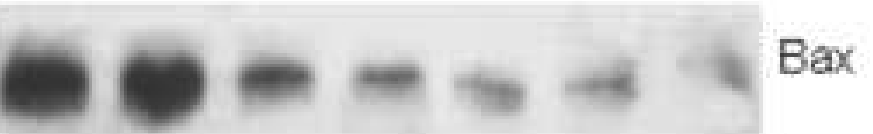

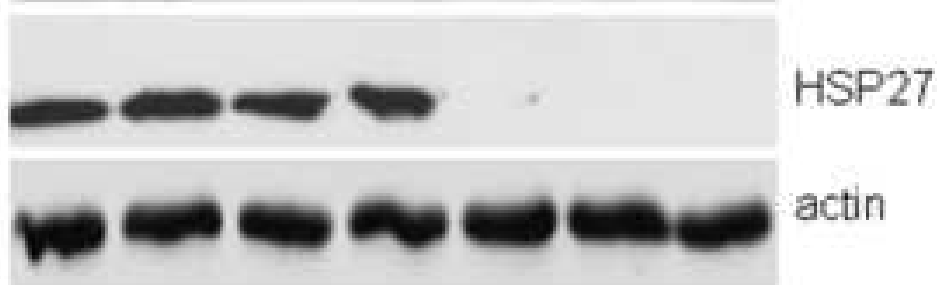
cleaved caspase 3

PARP actin 